\title{
HID ランプの小型コンパクト化
}

\author{
専門会員三好 和彦* 専門会員 祝 郁夫*
}

\section{1. は じめに}

一般照明用光源の性能の主眼は，いうまでもなくランプ 効率および演色性である. HID ランプにおいても年々の 技術進歩により図 1 に示すように, 高性能化つまり高効 率化, 高演色性化が達せられつつある. このことは一般照 明のそれぞれの分野に対して，ルーメンパッケージの一定 必要量が存在する以上, 必然的にランプの小型化に向から 要請となって現われる.

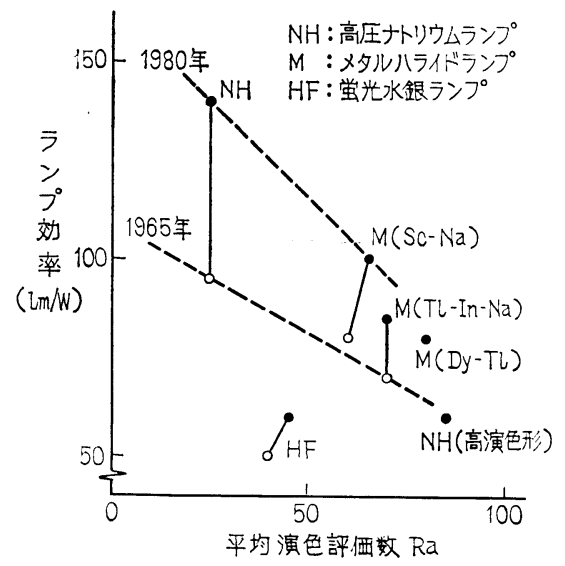

図 1 HID ランプの効率と演色性

一方，屋内照明特に家庭用として多用されている白熱電 球に代替できる小型高性能の新光源の探索が，最近非常に 盛んである. 白熱電球のように小型で使用簡便かつ高演色 性であって，さらに蛍光ランプのように高効率の光源が, HID ランプとして実現可能であるか種々検討されている.

このような背景の下で, HID ランプの小型コンパクト 化に関する最近の技術動向について吟味してみたい。図 1 に見るよらに最近の HID ランプの技術上の進展は，もっ ぱらメタルハライドランプと，高压ナトリウムランプに集 中している. 水銀ランプは, 特性の安定性，価格などに抏 いて現在も高い商品価值を有しており， $40 \mathrm{~W}$ までの小型 化, 電球色ランプの実現, 安定器内蔵形ランプを含めて豊

† Some Aspects on Low-wattage HID Lamps

* 岩崎電気俱 Kazuhiko Miyoshi, Ikuo Iwai
富な品数と屋内照明用光源としても魅力的な条件を備えて いるが，効率の点でメタルハライドランプや高圧ナトリウ ムランプに及ばず，技術的にも成熟したものであるので， 本稿ではもっぱらこの二つのランプについて述べる.

\section{HID ランプ小型コンパクト化の問題点}

HID ランプを小型コンパクト化しよらとすると，さま ざまの問題に直面する. その多くは中高ワットのランプと 共通する問題が，小型コンパクト化することで強調されて いるように思われる，このよらな問題を解決することは困 難は多いが，HID ランプが屋内照明などの分野で受け入 れられるためには，ぜひ解決されなければならない。

\section{1 ランプ効率および演色性}

HID ランプは, 高強度放電 (HID) 自体の発熱により 高い発光金属蒸気圧と高いアーク温度を確保し，このこと によって，高いランプ効率と優れた演色性を得ることを特 徵としている. この性質のゆえに HID ランプを小型化し ようとするとき，まず直面する問題が，小さい電気入力で いかにして高い蒸気圧とアーク温度を維持するかといらこ とである. ランプを低ワット化していくと，ランプ入力の うち, 放電加熱に消費される部分（熱損失）が相対的に増 加し，図 2 に示すようにランプ効率の低下となって現わ れる.

熱損失の割合の増加を抑制するための有効な手段は，発

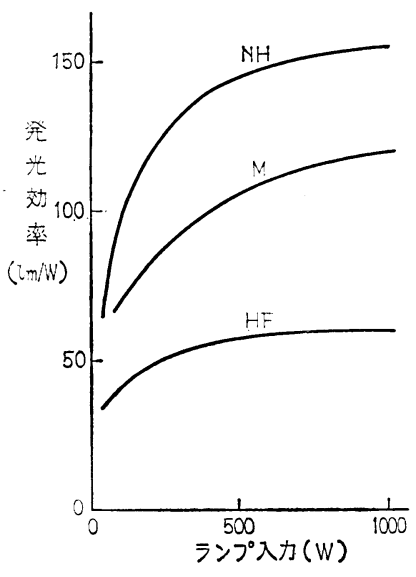

図 2 HID ランプの入力電 力と効率 
光管端部への熱流出を抑えることである.このため単位ア 一ク長当たりの入力を増し, 発光管端部寸法を小さくする ことが行なわれる.

メタルハライドランプの場合, 典形的な管形状は, 封止 部分をできるだけ小さくした棱円体である，単位アーク長 当たり入力を増すことにより生ずる, 石英管壁の温度上昇 の問題を管中央部径の增大により解決するとともに，封止 プレス面からの熱損失を小さくするものである，楕门体形 状には，鉛直点灯時, 対流によって効果的にハロゲン化物 蒸気を管上部まで運ぶことができる利点もある1

高圧ナトリウムランプの場合，このようなランプ形状は ナトリウム蒸気の光学的厚みが増すことにより, ナトリウ 厶の吸収が大きくなるので, 効率改善の手段としては効果 的でない，D線の吸収を積極的に利用した高演色形高圧ナ トリウムランプの場合には, 端部からの熱損失を小さくす る上で効果がある。その他，管壁からの熱放射損失を抑え るため，管壁のエミッシビティーの調整などが検討されて (るる2).

発光物質の選択範囲の広いメタルハライドランプでは, 複合分子を利用して，比較的低温で高い蒸気圧を得る方法 も試みられている. たとえば $\mathrm{NaScI}_{4}$ の蒸気圧は, $\mathrm{ScI}_{3}$, $\mathrm{NaI}$ それぞれ単体の蒸気圧よりも高く， Ce や $\mathrm{Nd}$ などの 軽希土類と Cs の複合ハロゲン化物も効果的な高蒸気圧を 得る化合物として知られている4)5).

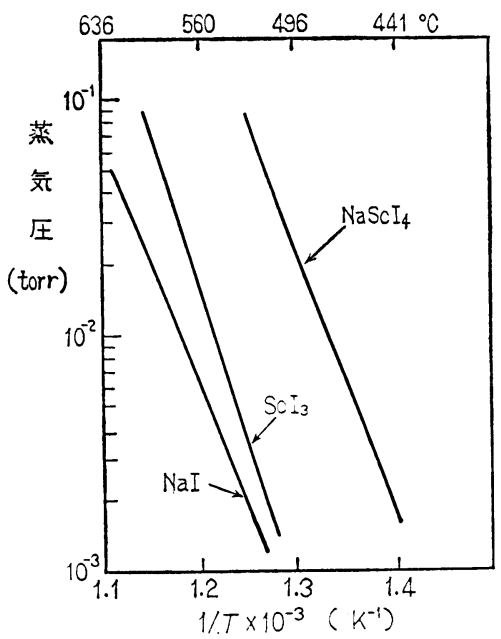

図 3 複合分子と単体の蒸父王:

\section{2 始動, 立ち消え}

ランプを小型化すると，容積に比し管壁面積が大きくな り，また管壁が接近するので，イオンの消隇速度が增すこ とになる，その結果，交流点灯したときの再点弧電压が上 昇し立ち消えしやすくなる，また始動電圧も高くなりやす い.このことは，メタルハライドランプにおいて特に顕著 である，管径を大きくしたり，始動特性を左右する不純物 の混入に特に意を用いるなど，ランプ側からのアプローチ のほか点灯回路の検討も活発に行なわれている ${ }^{6)}$.

再点弧電圧の上昇をさけるために, 直流点灯や高周波点 灯によって消弧時間を無くするか短くして, 消弧中の急速
なインピーダンス増を最小にすることが行なわれる．高周 波点灯の場合，周波数によっては篦的共鳴現象のために アークがゆれたり，立ち消えを起こしたりすることがあ り，解決案が種々検討されている7)8.

小型ランプは，屋内照明に使用される機会が多いので， ランプの立ち上がり特性（始動時間）が早いこと, 瞬時再 点灯が可能なこと, $100 \mathrm{~V}$ 電源で簡便に点灯できることな どへの要望が強い，しかし，高圧の金属蒸気放電灯である HID ランプはこの点不利であり, これらの要求をカバー するために，点灯回路側からのアプローチが積極的になさ れている9).

\section{3ちらつき}

屋内照明を考虑すると，アークのゆらぎやちらつきは極 力低減しなければならない. HID ランプを商用周波数 (50 $\mathrm{Hz}, 60 \mathrm{~Hz}$ ) で点灯すると, 電源半サイクルごとの発光量 に不ぞろいが生じたときちらつきを感ずることがある。ち らつきを感ずる程度は周波数と輝度に依存するが，通常の ランプでは, 周波数は電源周波数, 輝度は照明条件によっ て決まるので, 電源半サイクルごとの発光波形のピーク值 を比較することでランプの評価ができる(10)11).

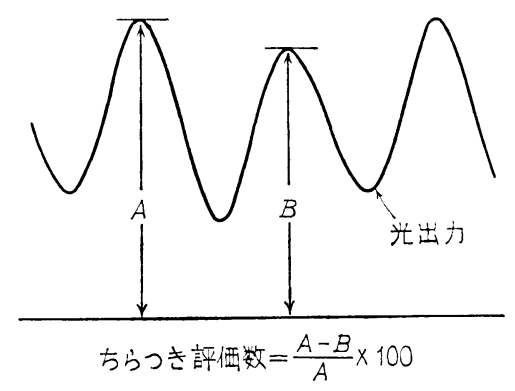

図4ちらつきのあるランプ発光波形

ちらつきは, 電極の設計と密接にかかわると推定され， 寿命特性や始動特性を損らことなく，ちらつきを低減する 電極設計が必要である ${ }^{12) 13)}$. また高周波数点灯や直流点灯 では，ちらつきが問題とならないので点灯回路の検討も必 要である。

\section{4 寿命}

光束堿退のほか, 始動電圧や再点弧電圧の上昇, ランプ 電圧の上昇, リーク, 色変化など中高ワットと共通の寿命 要因が，小型コンパクトランプではより強調される傾向に ある. 白熱電球代替光源として HID ランプを考えると, コスト面から見て， 5, 000 6,000時間以上の寿命が要求さ れると思われるが, 小型コンパクト HID ランプが普及す る上で, 寿命の安定化は必須の条件である.

アーク長が短くなると, 電極物質の蒸発による端部黒化 の光束減退に及ぼす影響が大きくなるので, 電極の設計や 不純物の混入防止が重要である。また管壁負荷が増し，管 壁温度や封止部温度が高くなると, 封入物質と管壁材料あ るいは封止材料や電極との反応が重要な要因となる．この ランプ内の化学反応については，十分解明されているとは いえず，寿命を長くするためさらに研究を要する. 
3. メタルハライドランプ小型コンパクト化の 傾向

\section{1 低ワットメタルハライドランプ}

一般照明用としては，国内では高效率，低始動電圧形の $100 \mathrm{~W}$ と高演色形の $125 \mathrm{~W}$ が材販されている。表 1 にこれ らの特性を示与。

表 1 低ワットメタルハライドランプの特性

\begin{tabular}{l|r|r|r|r|r}
\hline ランプ形式 & $\begin{array}{c}\text { 全 光 束 } \\
(\mathrm{lm})\end{array}$ & $\begin{array}{c}\text { 発光効率 } \\
(\mathrm{lm} / \mathrm{W})\end{array}$ & $\begin{array}{c}\text { 色 温 度 } \\
(\mathrm{K})\end{array}$ & $\begin{array}{r}\text { 平均演色 } \\
\text { 評 価 数 }\end{array}$ & $\begin{array}{c}\text { 平均寿命 } \\
(\mathrm{Hr})\end{array}$ \\
\hline $\mathrm{M} 100 \cdot \mathrm{L}$ & 7,000 & 70 & 3500 & 60 & 6,000 \\
\hline $\mathrm{D} 125$ & 4,700 & 38 & 5000 & 92 & 6,000 \\
\hline
\end{tabular}
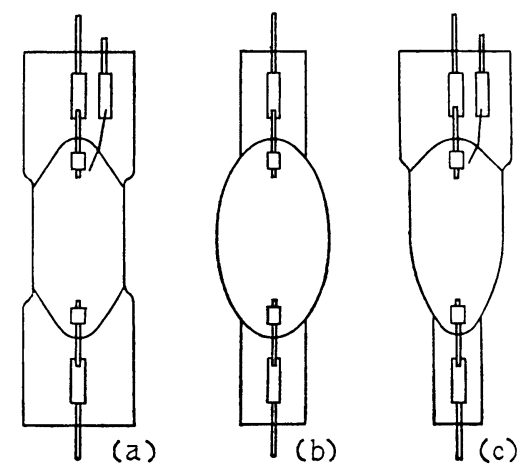

図 5 小型メタルハライドランプの 発光管

（a）深い封止形状，(b) 桶円体形，

(c) 小さい封止部 (下側だけ)

小型化に伴い，相対的に大きくなる端部からの熱損失を 小さくし，八ロゲン化物が蒸発するに十分な温度を保つた め発光管形状に種々の工夫がなされている1144) (図 5). 発 光物質としては, 高効率形は Tl-Na-In 系や Sc-Na 系 が，高演色形は Sn 系が選ばれているが，最近，高効率と 高演色性を兼齐備えたものとして，欧州を中心に $\mathrm{Sn}-\mathrm{Na}$ 系 ${ }^{15)}$ や $\mathrm{Tm}-\mathrm{Na}-\mathrm{Tl}$ 系 ${ }^{16)}$ などが研究されている.

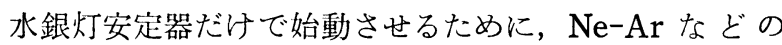
ペニングガスが利用されるが，効率の点から熱伝導率の大 きな $\mathrm{Ne}$ ガスを使用しないで，ランプ内にグロースタータ を組み込む方式も行なわれている（図 6).

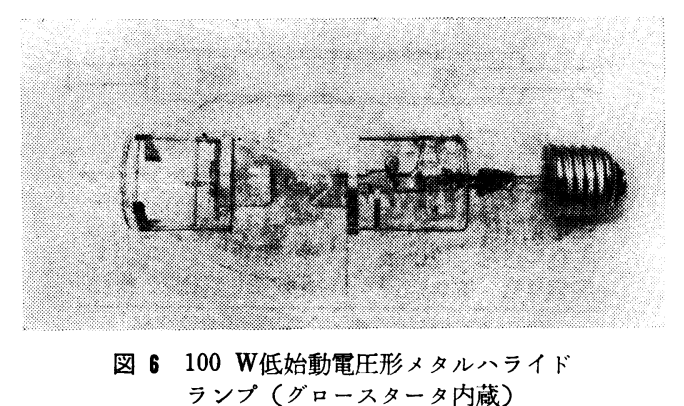

最近欧州のメーカから $70 \mathrm{~W}$ のランプが発表され17)， 、 タルハライドランプも，水銀ランプや高圧ナトリウムラン プ同様， $100 \mathrm{~W}$ 未満の低ワットランプがシリーズ化される ものと予想される.

\section{2 安定器内蔵形コンパクトメタルハライドランプ}

1979年米国で, 安定器を内蔵し電球ソヶットに適合可能 なコンパクトメタルハライドランプが発表され，白熱電球 代替光源としての HID ランプが，にわかにクローズアッ プされてきた。

Davenport ら 9) の報告によると，発光管は棈円体形で， 内容積は $30 \mathrm{~W}$ 設計で $0.11 \mathrm{~cm}^{3}$ と非常に小さい。端部を 極端に小さくして，端部損失を最小にした設計となってい る.棈円体のため, 単位アーク長当たり入力が大きいわり には管壁負荷は大きくないが, 石英温度は $1,000^{\circ} \mathrm{C}$ にも達 している，通常このような高い温度で使用して，長寿命は 得られないとされていたが，長時間の点灯でも失透などは 見られなかったと報告している。

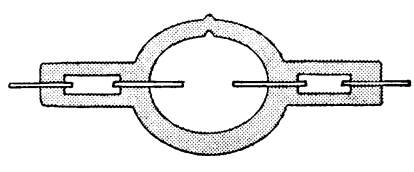

(a)

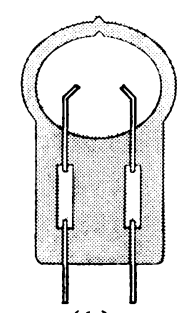

(b)
図 7 安定器内藏形コンパクトメタル ハライドランプの発光管 (a) 棈円体両側封止形 (b) モノシール形

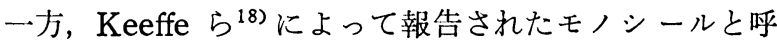
ばれる発光管は，片側だけに封止部が存在するので, 両側 封止の場合よりも大きい封止部になる。したがって強度や 製造面でのメリットがある（図 7 (b)).

光束維持に影響する要因として電極は重要であるが, Davenport らは，アーク端と電極間のエネルギーバラン スから最適設計をすることによって，電極に起因する光束 減退をほとんどなくすることができたと報告している。

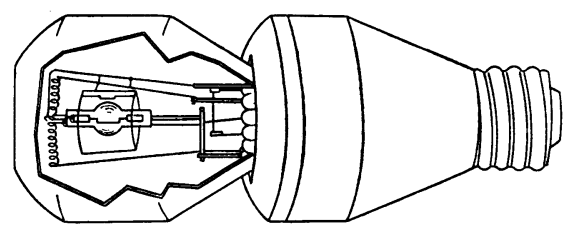

図 8 安定器内藏形コンパクトメタル ハライドランプ (GE 社)

Davenport らのランプは，图８に示すように電子安定 器と一体にして，白熱電球ソケットにとのまま適用できる 構造になっている. 点灯方式はトランジスタインバータ駆 動による高周波点灯であり，再点弧電圧の低減，軽量化な ぞの狙いがある．高周波点灯に伴う音響的共鳴現象をさけ るために共鳴を起こさない周波数帯を選んでいる．白熱電 球代替のためには点灯の即時性が要求されるので，ランプ 内にタングステンフィラメントを配置し，始動時や再始動 時, 発光管から十分光量が得られない間, フィラメントを 発光させるよらになっている。

安定器部分を含んだランプの詳細な特性が公表されてい

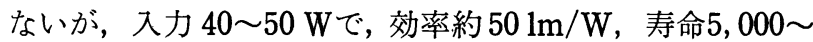




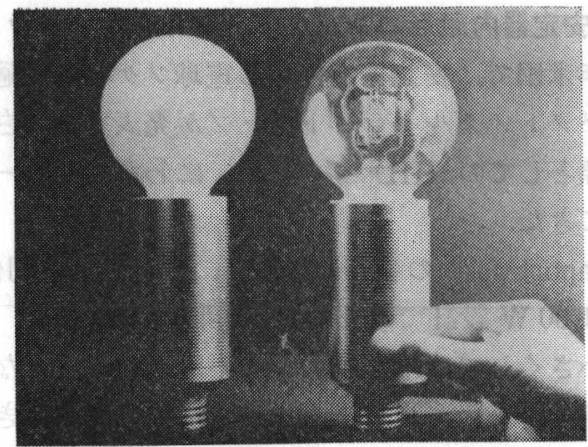

図 9 安定器内蔵形コンパクトメタル ハライドランプ $(35 \mathrm{~W})$

7,500時間である.

国内でも同種のランプの研究が活発に行なわれて和り， 最近発表されたランプは, 安定器も含んで入力電力 $35 \mathrm{~W}$ と HID ランプとしては最も小さく, 効率 $50 \mathrm{~lm} / \mathrm{W}$, 寿命 5,000 時間と優れた特性となっている. 発光管の加工に レーザを用いるなど，製造面でも新しい試みがなされてい る ${ }^{19)}$.

今後, 電球代替用の安定器内蔵形ランプの製品化が進む と思われるが, 白熱電球の持つ使用の簡便さ, 優れた演色 性などをあまり損らことなく，HID ランプの高効率性を 生かした経済性のあるランプにすることが望まれる. 白熱 電球に比べると初期コストが高くなるので，それをどの程 度まで低減できるかが普及のキーポイントとなろう。

\section{3 セラミック・メタルハライドランプ}

1981年のハノーヴァ・メッセにセラミック製の発光管を 使ったメタルハライドランプが出展され20), 注目を集め た. 透光性アルミナ管は, 高圧ナトリウムランプで実績の あると打り優れた耐熱性と化学安定性を持っており, メタ ルハライドランプに適用して，より広範囲のハロゲン化物 の利用の可能性と高効率, 長寿命のランプが期待される. すなわち, アルミナ管は高温での安定性が優れており, 蒸 気圧の比較的低いハロゲン化物の使用が容易になるほか， 石英から遊離した Si による電極変形などがないと予想さ れる。

それだけに，ハロゲン化物と反応しない材料で構成され なければならず, 従来の高圧ナトリウムランプに使用され ている $\mathrm{Nb}$ などの金属や，アルカリ土類酸化物を含む封着 材を使用することができない21). Brown ら ${ }^{22)}$ は, 図 10 のように, タングステンとアルミナのサーメット ${ }^{21)}$ 耐八 ライド封着材を使用し, 発光物質として $\operatorname{SnNaX}_{3}(\mathrm{X}=\mathrm{Cl}$,

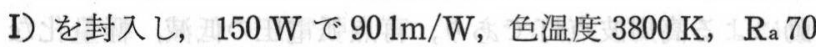
以上を得たと報告している。

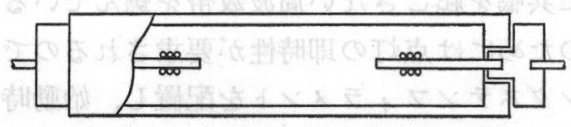

図 10 セラミックメタルハライド ンプ発光管

セラミック管の利用は緒についたばかりで, まだメタル ハライドランプの方向を左右するほどには至っていない
が，セラミックの特性を生かした新しいランプの出現が期 待される.

\section{4. 高圧ナトリウムランプ小型コンパクト化の 動向}

\section{1 高効率形高圧ナトリウムランプ}

欧米ではすでに, 表 2 に示すような低ワット高効率形 高圧ナトリウムランプが市販されている. ランプ電圧 $50 \mathrm{~V}$ 級と $90 \mathrm{~V}$ 級の 2 種に大別できるが，これは各々，米国の $120 \mathrm{~V}$ 電源, 欧州の $220 \mathrm{~V}$ 電源に拈いて, チョーク形安定 器のコストミニマムを狙って設定されたものである.

表 2 低ワット高効率高圧ナトリウムランプの仕様, 特性

\begin{tabular}{|c|c|c|c|c|c|c|c|}
\hline 大きさ (W) & 35 & 50 & 70 & 100 & 50 & 70 & 100 \\
\hline ランプ電圧 (V) & 52 & 52 & 52 & 55 & 85 & 90 & 100 \\
\hline ランプ電流 (A) & 0.83 & 1.18 & 1.6 & 2.1 & 0.75 & 0.98 & \\
\hline ランプ光束 $(\mathrm{lm})$ & 2,250 & 4,000 & 5,800 & 9,500 & 3,500 & 6,100 & 9,500 \\
\hline ランプ効率 $(1 \mathrm{~m} / \mathrm{W})$ & 64 & 80 & 83 & 95 & 70 & 87 & 95 \\
\hline 色＼cjkstart温＼cjkstart度 (K) & 1900 & 1900 & 1900 & 2100 & 1850 & 1900 & 1925 \\
\hline 始 動 方 式 & $\begin{array}{l}\text { イグナ } \\
\text { イタ }\end{array}$ & $\begin{array}{l}\text { イグナ } \\
\text { イタ }\end{array}$ & $\begin{array}{l}\text { イ゙ナ } \\
\text { イタ }\end{array}$ & $\begin{array}{l}\text { イ゙ナ } \\
\text { イタ }\end{array}$ & 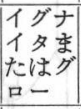 & $\mid \begin{array}{l}\text { イグナ } \\
\text { イタま } \\
\text { たはグ } \\
\text { ロー }\end{array}$ & $\begin{array}{l}\text { イグナ } \\
\text { イタ }\end{array}$ \\
\hline ランプ全長 (mm) & 140 & 140 & 140 & 140 & 156 & 156 & 186 \\
\hline 口 金 & E27 & E27 & E27 & E27 & E27 & E27 & $\mathrm{E} 40$ \\
\hline
\end{tabular}

現在, 市販ランプで最も低入力のものは $35 \mathrm{~W}$ である が, これの全光束は, $150 \mathrm{~W}$ 白熱電球と同程度の $2,250 \mathrm{~lm}$ である.これ以上入力の低いランプは, 用途面から必要と されないのではないかと推定する.

色特性は，一般形高圧ナトリウムランプとほぼ同様であ る. 色温度が低過ぎる, 赤の演色性が良くないといった理 由で, 一般家庭などの屋内照明には不適と思われる. 欧米 では, 玄関灯, 保安灯など建物周りで多用されている. 白 熱電球の 4.5 倍, 水銀ランプの 2.5 倍のランプ効率のゆえ に, 省エネルギーを目的として, これらのランプに代わっ て用いることが多いようである.わが国でも $70 \mathrm{~W}$ 以上の $50 \mathrm{~V}$ 級, $90 \mathrm{~V}$ 級の高圧ナトリウムランプがすでに市販さ れている. $35 \mathrm{~W}, 50 \mathrm{~W}$ 発売の動きもあるが, 高い初期コ ストが障害となってまだ普及するに至っていない。

ランプ構造は, 図 11 のように中高ワット高圧ナトリウ
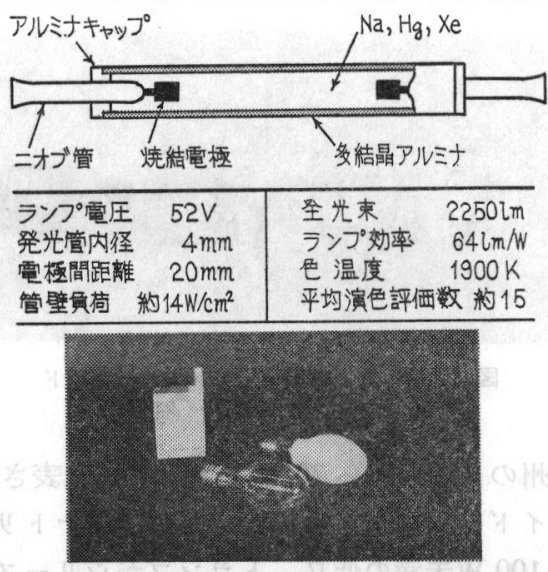

図 1135 W高压ナトリウムランプの 構造特性 
ムランプとおお括ね相似形である. 低入力高圧ナトリウム ランプ発光管の設計に際しては, $\mathrm{Na}$ 蒸気, 温度（アーク 温度，管壁温度，最冷部温度など）をそのまを維持した上 で, ランプ入力, ランプ電流（または電圧）, 発光管寸法, $\mathrm{Na}$ 封入量などの設計要素をスケールダウンしていく必要 がある. しかし電極, 封止構造, 算電りードなどの発光管 端部の縮小化には限界があり，このため端部損失増大によ ってランプ效率が低下する. 発熱量不足によって Na 蒸気 圧の維持が困難となる, あるいは電極動作不安定によっ て，ランプ特性のばらつきが増大するなどの問題を生ず る. $\mathrm{Nb}$ 細線による封此 ${ }^{23)}$, 発光管端部への保温板の付 設 ${ }^{24)}$, 含有エミッタ量が多く, 寸法, 熱特性再現の良い焼 結形電極の採用 ${ }^{25)}$ など，種々の工夫が提案され実施されて いる.

点灯方式は, $90 \mathrm{~V}$ 級ではランプに内蔵したグロースタ 一タ，50 V 級では独立したイグナイタが一般的である. いずれもパルス電圧を $3 \mathrm{kV}$ 程度に抑觉ているが，これは 低入力高圧ナトリウムランプが，E26といら小さく耐電压 の低い口金を用いるためである.

\section{2 高演色性形高圧ナトリウムランプ}

高压ナトリウムランプにおいて, $\mathrm{Na}$ 蒸気压を増すと $\mathrm{Na}$ のD線が広がって来る.

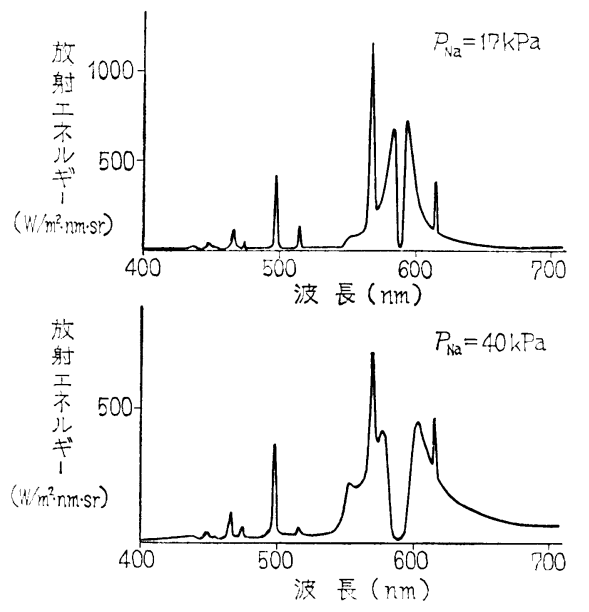

図 12 高圧ナトリウムランプの 分光エネルギー分布

図 12 のように，可視光波長域の全域に放射されるよう になり, 色温度が高くなり演色性が向上する. 現在, 中高 ワットでは $\mathrm{R}_{\mathrm{a}} 60$ のものが演色改善形として ${ }^{28)} ， \mathrm{R}_{\mathrm{a}} 80$ の ものが高演色形として ${ }^{29)}$ 市販されている.

これらのランプの色特性こそ屋内照明にふさわしく, 当 然に低ワット化が検討されている. 特に高演色形高圧ナト リウムランプの光源色, 演色性は, 白熱電球に良く近似し ており，屋内照明用省エネルギーランプとして大いに期待 される. このランプの $590 \mathrm{~nm}$ の自己吸収の谷を持つ発光 スペクトル分布は, 被照明色の彩度を上げるという3 波長 蛍光ランプと同様の効果を発揮する.

高圧ナトリウムランプにおいても, 演色性とランプ効率 の相克は避けがたい. しかし, 最近発光管管壁負荷を通常
の 2 倍以上の $35 \mathrm{~W} / \mathrm{cm}^{2}$ とすれば, $40 \mathrm{~lm} / \mathrm{W}, 2,000 \mathrm{~lm}$ の $50 \mathrm{~W}$ 高演色形高圧 ナトリウムランプを実現できるという 注目すべき報告があった ${ }^{30)}$ 。低ワットに拈いては，発光管 端部への熱伝導率増大に伴って，管壁温度の相対的低下の あることに着目したもので，図 13 のよらな発光管形状に よる $\mathrm{Na}$ 蒸気圧増大方法の併用により, 長寿命の実用ラン プが得られるとしている.

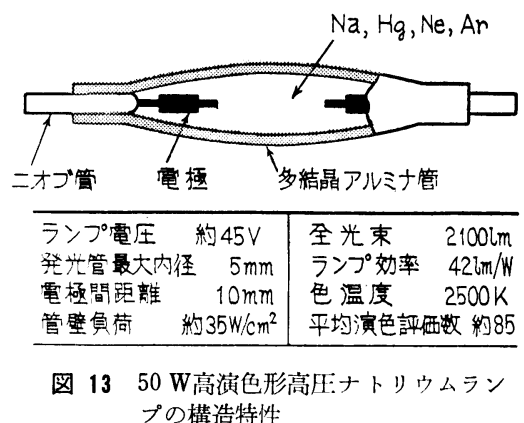

演色改善形でも $85 \mathrm{~W}$ が発表されている ${ }^{6)}$. 発光管端部に 設けた金属保温板で $\mathrm{Na}$ 蒸気圧を増大させており，66 lm/ $\mathrm{W}, \mathrm{R}_{\mathrm{a}} 60$ の特性を得ている. このランプの点灯には小型 HID ランプの用途分野に適した，小型軽量で $100 \mathrm{~V}$ 電源 用の毎サイクル点灯方式のハイブリッド電子安定器を採用 している.

\section{5. むす び}

以上, HID ランプ小型コンパクト化の現状について 概 観した。白熱電球代替光源としては, 安定器内蔵形の蛍光 ランプが急速に普及しつつあるが，HID ランプはこれよ りもやや大きなルーメンパッケージの必要な分野に進出す ると思われる. ランプおよび点灯装置に関する技術的な問 題点については次々に解決しつつあるが，最終的には初期 コストをどの程度引き下げ得るかが，普及のかぎをにぎっ ていると思われる。

最後に，本稿の執筆に当たり快く資料をご提供下さった 東京芝浦電気秼の井上昭浩氏と，日立照明秼小山敦夫氏に 感謝します。

\section{参 考 文 献}

（1）中村 昇ほか：100 W タルハライドランプ, 昭54照学全 国大会（昭54） 18

(2) Waymouth, J. F. et al: Analysis of factors affecting efficacy of high pressure sodium lamps. J. Illum. Engng. Soc. 10-4 (1981) 237

(3) Van Vliet, J. A. J. M. et al: The influence of the wall temperature on the luminous efficacy of high pressure sodium lamps. 3 rd International Symposium on the Science and Technology of Light Sources (1983) 60

(4) Hirayama, C. et al: Complex halide vapors in metal halide type HID lamps. J. Illum. Engng. Soc. 6-4 (1977) 209 
(5) Liu, C.S. et al: Spectrophotometric study of alkalirare earth iodide vapor complexes and their application to HID arc lamps. J. Illum. Engng. Soc. 8-3 (1979) 147

(6) 井山博之ほか：小出力高圧ナトリウムランプの毎サイクル 点弧形電子安定器による点灯, 照学誌 67-6 (昭58) 266

(7) 越村安信ほか：HID ランプの高周波点灯における放電安 定化方法, 照学誌 67-2 (昭58) 55

（8）越村安信ほか：小型メタルハライドランプ用電子安定器の 開発，昭58照学全国大会（昭58）47

(9) Davenport, J. M. et al: Low wattage metal halide lamps. J. Illum. Engng Soc. 11-2 (1982) 66

(10) 腰原正彦ほか：HID 光源のちらつき現象の一考察, 昭55 照学全国大会（昭55） 31

(11) 清水智恵子ほか：放電ランプのちらつき不快感の定甾評 価, 昭57照学東京支部大会 (昭57) 12

(12) 村瀬隆幸ほか：メタルハライドランプの電極構造とランプ 特性の検討, National Tech. Rep. 27-3 (昭56) 62

(13) 島谷俊彦ほか: $100 \mathrm{~W}$ メタルライドランプの新電極, 昭 58照学全国大会（昭58） 37

(14) 神谷明宏ほか：小ワット・高効率 HID ランプ, 東芝レビ 上一 37-2 (昭57) 101

(15) Whittaker, F. L.: Properties of sodium tin halide-mercury discharges. Light. Res. Technol. 13-1(1981) 11

(16) Tielemans, P. et al: Spectral properties of metal halide lamps with rare earth and Sc additives, $3 \mathrm{rd} \mathrm{In-}$ tern. Symp. on the Sci. Tech. Light Sources (1983) 121

(17) Progress '82, Light. Des. Appl. 12-12 (1982) 19

(18) Keeffe, W. M. et al: Factors in the design of scandium sodium iodide arc discharge lamps. IES Conference,
Preprint (1980)

(19) 持丸真次ほか：小型メタルハライドランプのレーザ加工に よる水素の減少，昭58照学全国大会（昭58） 37

(20) Odell, E. C. et al : Light sources. J. Chart. Inst. Build. Serv. 3-6 (1981) 32

(21) Hing, P.: Interaction of alkali metal and halide vapors with ceramic materials. J. Illum. Engng. Soc. 10-4 (1981) 194

(22) Brown, K. E. et al: Tin sodium halide lamps in ceramic envelopes. J. Illum. Engng Soc. 11-2 (1982) 106

(23) McVey, C. I.: High pressure sodium lamp seals and recent improvements. J. Illum. Engng. Soc. 8-2 (1979) 72

(24) 広瀬吉夫ほか：新しい高圧ナトリウムランプ・ネオルック スー70 Wと低始動形一，東芝レビュー 32-9（昭52）731

(25) 下垣光太郎ほか：高王ナトリウムランプ用電極, 昭58照学 企国大会（昭58） 57

(26) Mizuno, H. et al: New high-pressure sodium lamp with high color rendition. CIE XVII Cession, Barcelona (1971) 14

(27) Van Vliet, J. A. J. M. et al: High-pressure sodium discharge lapms. IEE Proc. 128 A-6 (1981) 415

(28) Otani, K. et al: A high pressure sodium lamp with improved color rendition. J. Illum. Engng. Soc. 11-4 (1982) 231

(29) 斉藤直樹ほか：屋内照明用 HID ランプー演色本位形高压 ナトリウムランプー＼cjkstart照学誌 63-5 (昭54) 272

(30) 尾形芳郎ほか：50 W 高演色性高圧ナトリウムランプ, 昭 58照学全国大会（昭58）61

（受付1983年 7 月18日） 